\title{
CONCEPTS OF CURRICULUM IN PEDAGOGICS ABROAD
}

The article aims at studying the concept characteristics of curriculum in the ideas of foreign researchers in terms of its definition, meaning, and classification of its types, levels and strategies for the development. The article presents the origin and meanings of the term "curriculum", which in education refers to any course or activities that result in the development of a person; and covers prescribed content of learning during period of compulsory education. It is found out that the concept background of the school education content in the United Kingdom of Great Britain and Northern Ireland is determined by the curriculum theory. Based on the research of curriculum studies the types of curriculum (subject centered, society centered, child centered; curriculum as syllabus, curriculum as process, curriculum as product) as well as its levels (total, hidden, planned and received, formal and informal) are analysed. The differentiation of the curriculum levels is a very important issue as to comprehension of this pedagogical phenomenon. The outlined in the article curriculum levels are total; hidden; planned and received; formal and informal. The classification is made according to the audience for which they are addressed; and it gives a clear illustration of their practical application. Special attention is paid to classification suggested by van den Akker that proves the social nature of this phenomenon. Hidden curriculum and its nature is under discussion in the article. It is presented as the transmission of norms and values conveyed in the educational institution is characterized in the study. The diversity of approaches to the classification of curriculum types and levels provides evidence to support the claim about complex character of this pedagogical phenomenon.

As for the primary curriculum, it is exposed, that this pedagogic reality is connected with its developmental type; and nowadays it is getting global characteristic. Primary curriculum is considered as framework in which according to the defined aims knowledge, practical, values, personality characteristics, which pupils should obtain, are determined.

Key words: curriculum, concept, curriculum theory, types, levels, European educational system.

The statement of a problem. Content of education is one of the main subject of the research in educational science of Ukraine and many European countries. Concept basics of the education content in the United Kingdom of Great Britain and Northern Ireland defines the 
curriculum theory, whose analyses give opportunities to characterize varies levels, types and models of curriculum, outline its usage in the level of different countries. Curriculum is a widely discussed educational project in terms of its definitions and objectives for educational institutions as the approaches to the curriculum theory and practice are changing influenced by new tasks faced the society. Therefore, understanding of this phenomenon is important for defining strategies for further development of the education system.

Analyses of the latest research. Curriculum studies is a field of research for quite a lot scientists. The research of education content in Great Britain that was carried out by A. Ross and other British educators is based on the theory of curriculum. Needless to say that in a global context curriculum is transforming from quite AngloAmerican pedagogical phenomena to European education project. And the term "curriculum", that comprises the structure, transforming and assessment of the social experience obtained by pupils within the educational institution, is becoming international one [1, p. 82]. The term "curriculum" is officially used in Great Britain, the USA, Ireland, Italy, the Netherlands, Portuguese, Rumania and Flemish Community of Belgium [2, p. 22].

The literature review process shows that the term "curriculum" is formally appeared in University Leiden records in 1582 and later in University of Glasgow in 1633 [3]. The first known use in the written work is in The Oxford English Dictionary, where it was defined as compulsory course of study or training course in educational institution.

The word "curriculum" comes from the Greek word "a running', "a course". The original Latin meaning was 'a race course', "career" [4]. British researcher A. Ross gives another idea referred to the origin and meaning of this notion. According to A. Ross Latin word referred to a racing chariot |from which is derived| a racetrack, or a course to be run, and from this, a course of study. In developing the idea in education, curriculum is confined to any course or activities that result in the development of a person; and prescribed content of learning during period of compulsory education $[5, \mathrm{p} .8]$.

The starting points of Ukrainian educators on curriculum idea is that this educational phenomena referred to core of learning - course of study, syllabus, subjects programmes of study, and in wider 
meaning it includes educational content, programmes, methods, structures, visual aids, all kinds of educational literature, including printed textbooks [6, p. 160].

Using educational concepts, C. Braslavsky, the director of International Bureau of Education, defines the educational foundations and contents, their sequencing in relation to the amount of time available for the learning experiences, the characteristics of the teaching institutions, the characteristics of the learning experiences, in terms of methods to be used, the resources for learning and teaching (e.g. textbooks and new technologies), evaluation and teachers' profiles [7, p. 5].

The article aims at curriculum concepts studying in education system of Europe in terms of its definition, meaning, and classification of its types, levels and strategies for development

The statement of the main materials. A glance at the history of the curriculum field suggests that the curriculum is one of the most effective tool for bridging the gap between the education and development. Some curriculum practitioners, particularly those in Ireland tradition represent curriculum as a combination of educational, economic, social and cultural developments in Irish society primary curriculum as reflection of cultural, social, economic intends and ideas of the society; the culmination of many years of development and planning that involved all the partners and interests in primary education $[8, \mathrm{p} .10]$.

Curriculum as a field of study is far from being new in education science. Curriculum questions include curriculum theory, development, implementation and assessment. The theoretical frameworks that comprise traditional, concept-empiricist and reconceptualist approaches to curriculum issues was suggested by American researcher H. A. Giroux. Each of these approaches is characterized by the dominant and subordinate assumptions that govern the knowledge and values underlining their respective modes of inquiry. According to traditionalists (F. Bobbit, R. Tyler, R. Peters, P. Hirst, A. Ross), curriculum is what will be taught in schools: educational objectives, curriculum, instruction, learning experiences, and evaluation [9]. Conceptual empiricists (H. Taba, J. Schwab, J. Bruner, B. Bloom, D. Lawton) view curriculum as the organization 
of disciplines; and the best way to learn a discipline is to learn and understand its structure. Reconceptualist (M. Young, M. Apple, W. Pinar, H. Giroux) connect the efficiency of curriculum with social, political and economic process in the society and refer to it as an effective tool for social changes.

It should be mentioned that there is no common format for curriculum concept in pedagogical science. Researchers can take into consideration different criteria of classification; these are aims, nature, purpose, content, structure. In order to make classification of curriculum types, researches use different notions, such as model, approach, center. For example, subject-centered, social-centered and child-centered (D. Lowton, 1976) [10, p. 52]; a body of knowledge to be transmitted, a product, a practice, a praxis (M. Smith, 1996); curriculum as content, process and as product (A. V. Kelly. 2004).

One can argue that each type has its own characteristics; describes the relationships between main components of education content. Every approach to curriculum classification has different set of aims and purpose, and defines particular way of implementation.

To have a clear overview of the curriculum it is necessary to analyse its levels depending on the audience for which they are addressed. To emphasize this aspect W. Kuiper (1993) proposes in his work to present 7 levels of curriculum. These are:

- Level 1 - imaginative, that is presented as the level of wishful thinking as all people have their own ideas of a good education;

- Level II - written curriculum which can be seen in Macrodocuments with formal status (national standards); Macro-documents without formal status (teachers' guidelines); Meso-documents which are accepted in school (programmes of study); Micro-documents that are presented by textbooks;

- Level III - perceived curriculum that is the way teachers interpret the ideas of written curriculum;

- Level IV- performed or operational curriculum in which resources provision of learning and time for it are indicated;

- Level V- experienced curriculum that was used by teachers and students in learning process;

- Level VI- tested curriculum that is set in tests in order to check the comprehension level of the content by students; 
- Level VII- learned curriculum defines the knowledge obtained by pupils in learning process.

So, one can make a conclusion that different facts and factors influence certain levels of the curriculum while analyzing their typologies suggested by scientists. According to W. R. E. Velema "fact" is a mediated factor of influence that has a long-term character and is designed for future results; "factor" is a motive power of rapid changes in education [11, p. 30]. For instance, educational and philosophic facts are leading at the "visible" stage. Political factors are of great importance at the "publishing" level as it is connected with the process of giving educational documents their official status. Other curriculum levels are to be acknowledged at macro-, mezzoand micro-levels within the school. It is worth taking into account the importance of a teacher's role, organizing the effective learning process, the research of the obtained results.

The differentiation of the curriculum between the levels is a very important issue as to comprehension of this pedagogical phenomenon. In 2006 a Dutch scientist Jan van den Akker suggested the classification of levels that gives the opportunity to observe their practical application (Table 1) [12, p.9].

Table 1

\section{Curriculum levels and its application according to Jan van den Akker}

\begin{tabular}{|l|l|l|l|}
\hline & \multicolumn{1}{|c|}{ Level } & \multicolumn{1}{|c|}{ Description } & \multicolumn{1}{c|}{ Examples } \\
\hline 1 & Supra & International & $\begin{array}{l}\text { - General European framed structure of } \\
\text { languages learning }\end{array}$ \\
\hline 2 & Macro & Systematic, national & $\begin{array}{l}\text { - major goals, achievements levels } \\
\text { - exam programmes }\end{array}$ \\
\hline 3 & Meso & $\begin{array}{l}\text { School, } \\
\text { educational institution }\end{array}$ & $\begin{array}{l}\text { - school programmes } \\
\text { - curriculums }\end{array}$ \\
\hline 4 & Micro & Grade, teacher & $\begin{array}{l}\text { - curricula, recommendations } \\
\text { - module, course } \\
\text { - text-books }\end{array}$ \\
\hline 5 & Nano & Student, personality & $\begin{array}{l}\text { - individual learning plan } \\
\text { - individual learning course }\end{array}$ \\
\hline
\end{tabular}

The classification of curriculum levels according to Jan van de Akker proves the social nature of this phenomenon. The scientist considers the following curricula levels to be major: total curriculum; 
hidden curriculum; planned and received curriculum; formal and informal curriculum.

The definition "hidden curriculum" was introduced by the American sociologist F. Jackson [13, p. 18]. But it existed in education much earlier. J. Dewey in his work "Experience and Education"(1938), described collateral learning that, in his opinion, influences much more than the above mentioned school curriculum[14, p. 96].

The Ukrainian researcher O. Plakhotnyk considers that the hidden curriculum is different from the evident in implicit or unconscious content of knowledge transmitted to students. The information in the hidden curriculum is transferred non-verbally or is hidden in the deep structures of the entire educational process [15, p.117].

According to S. Braslavskyi, "the hidden curriculum" stands as a united set of the educational experience and is not always considered to be compulsory and given in documents by schools and teachers in the process of practical activities.

The existence of the hidden curriculum as to the class differentiation (discriminative to the poor) can be an example. [7, p. 5].

The "planned" curriculum embraces all regulations of the learning process defined in programmes, plans and instructions. The "received" curriculum is a real result of pupils' learning activities.

The difference between the formal and informal curricula lies in the fact that the learning activities of the official curriculum are planned in accordance with the time-table and the main idea of the informal curriculum is applied in out-of-class activities during breaks, after classes, at weekends and during the holidays, in hobby groups and sections. The importance of the out-of-class activity in applying the curriculum is outlined in the report of J. Newsom (1963), head of the State Advisory Committee on education, in which he stressed the necessity to acknowledge such kind of activity as a part of the entire learning process [16].

Thus, the existence of the "total", "hidden" curriculum, acknowledgement of the difference between the planned and received results, the view of the curriculum as a division between formal and informal education prove the fact that it is an integral, social, flexible process that is planned and directed during the learning process or beyond it. 
The aims and the content traditionally make up the basis of this pedagogical phenomenon. In this context, van den Akker considers it as a multicomponent phenomenon in which every part performs its own function (Table 2) [12, p.12].

Table 2

Curriculum components in questions according

to Jan van den Akker

\begin{tabular}{|l|l|l|}
\hline & \multicolumn{1}{|c|}{ Component } & \multicolumn{1}{c|}{ Core questions } \\
\hline 1 & Rationale & What do they learn for? \\
\hline 2 & Aims and objectives & What are their goals? \\
\hline 3 & Content & What do they learn? \\
\hline 4 & Learning activities & How do they learn? \\
\hline 5 & Teachers' role & How does a teacher facilitate their learning? \\
\hline 6 & Materials and resources & What do they learn with? \\
\hline 7 & Grouping & Whom do they learn with? \\
\hline 8 & Place & Where do they learn? \\
\hline 9 & Time & When do they learn? \\
\hline 1 & Assessment & How is their learning assessed? \\
\hline
\end{tabular}

In his opinion all parts of the curriculum are connected with its levels. For instance, at the macro-level goals and content are at the first place compared with the learning activity that is connected with pedagogy, learning materials. At school and in class almost all components are equally important.

While considering the curriculum of primary school, Dutch pedagogues T. Boland and J. Letschett outline the components that, to their mind, form a common frame of primary education. They are:

- aims and objectives of primary education that have been greatly changed as to the unification under the influence of the European tendencies in the development of primary education;

- individual learning process that is a remarkable tendency and a new landmark of all European countries as to support and development of a person's potential;

- strengthening valuable landmarks aimed at rising a person's role and life value in the content of education of the European countries;

- length of compulsory education;

- teachers' autonomy as to the choice of effective learning methods;

- effective aim of learning and use of optimal technologies to estimate the level of pupils' key competences while learning the content. 
The curriculum of primary education is often connected with its developmental type suggested by the British scientist A. Blyth. In his work "English early childhood education" (1968) he outlines three types of curricula of primary education (using concepts "traditions"): preparatory, elementary and developmental [17, p. 16]. The scientist is convinced that the elementary curriculum was introduced at primary schools of England where teaching was aimed at the formation of pupils' main skills of reading, language and numeracy. The major goal of the preparatory curriculum is providing pupils with knowledge necessary for passing a selection exam to enter a secondary school. According to A. Blyth the developmental curriculum embraces the knowledge that promotes younger pupils' development. However, it should be stressed that some characteristics of the above-mentioned types are partly reflected in the modern curriculum of primary education [The same ref.].

Scientists A. Blenkin and A. Kelly further developed the idea of the developmental curriculum of primary education. Taking a view of the fact that the teaching process should be considered as a total combination of developing process that are to be developed and promoted by the curriculum, in the work "Early childhood education: a development curriculum"1996, the scientists focus the attention on the fact that the concept of the curriculum is based on the profound understanding the forms and methods of a child's development and on the practical learning activity that can promote this development. In the authors' opinion, in order to develop the curriculum of the early childhood education it is important not only to select the knowledge necessary for children but to define the goal of learning and the knowledge promoting their development. They stressed the need to plan the curriculum for primary school taking into account the connection between the knowledge that pupils naturally get themselves and the knowledge that pupils obtain in the process of learning certain subjects (Mathematics, Natural Sciences, Languages) and the knowledge to be developed in the process of the corresponding learning activities [18, p. 28-42].

Introduction of the term "the world curriculum" is the result of introducing the phenomenon of globalization as the progressive process of democratization and modernization into the theory of 
curriculum of primary school. These processes are connected with the name of the American sociologist and comparativist J. W. Meyer. The group of scientists at Stanford University (John W. Meyer, A. Benavot, D. Kamens) had been doing the analytical research of the international development of education since 1970. In 1992 they published the antalogy called "School education for the vast masses: world models and categories of the national curriculum for the primary school in the 20th century".

In this work the scientists state that since 1945 the countries of Europe had gradually formed so called unified curriculum of primary education that includes one or some national languages, Mathematics, Natural and Social Sciences, Art, Physical and Religious Education. On the basis of this fact J. W. Meyer suggested the idea of the curriculum at the elementary school where national or local peculiarities are less important. The scientist states that common features of different national educational systems prove the fact that school curriculum reflects the global world culture independent of national policy $[19$, p. 86].

Mayer's J. other idea dealt with increasing the accent in the curriculum on the expedient knowledge, the possibility of choice, taking into account the needs of every pupil.

In conclusion it is worth pointing out that education content as a key category of pedagogy is the subject of research done by a lot of comparativists in Ukraine, this proves the importance of the mentioned scientific problem. At the same time the issue of primary education content has been studying only in the context of the outlining tendencies in the development of the school education content, researching the content of some school subjects that does not provide the systematic description of the specific characteristics of the pedagogical phenomenon.

In the UK the education content in the British scientists' research is considered on the basis of the curriculum theory. The curriculum peculiarity is its diversity that causes the formation of different approaches to the classification of its types and kinds proving the complex character of this pedagogical phenomenon.

The analysis of the British pedagogical literature made it possible to define concretely the scientific content of the term "curriculum". It 
is defined as a pedagogical phenomenon, in which the social and teaching experience necessary for transmitting to pupils is determined and thus will provide the efficiency of the further learning process and make up the basis of knowledge, skills and habits necessary for the independent learning.

\section{References}

1. Lokshyna, O. (2009), Content of School Education in the European Union Countries (the second half - beginning of the 20th century): Monograph, Bohdanova A. M., Kyiv, p. 82.

2. Lokshyna, O. (2009), "Development of curriculum in European school education", Conference Proceedings on Pedagogical education: theory and practice, Kamianets-Podil., Vyp. 2, pp. 22-29.

3. Structure, functions and models of using modernized Curriculum, available at: http://www.cartier.md/upload/File/istorie_pag(1).pdf.

4. Kieran, Egan, (2003), "What is Curriculum? ", Journal of Canadian Association for Curriculum Studies, Vol. 1. No. 1, spring 2003, available at: https://jcacs.journals.yorku.ca/index.php/jcacs/.../15651

(accessed 20 December 2018).

5. Ross, A. (2000), Curriculum: Construction and Critique, GBR: Falmer Press, Limited, London, p. 8.

6. Klepko, S. (2006), Philosophy of education in European context: monohrafiia, POIPPO, Poltava.

7. Braslavsky, C. (2003), The Curriculum, IBE, Paris.

8. NCCA, (1999), National Council for Curriculum and Assessment. Primary School Curriculum. Introduction, Government Publication Sale Office, Dublin. Introduction, available at: https://www.mutah.edu.jo/userhomepages/drmajali/t1.html.

9. Scott, D. and Lawson, H. (2002), Citizenship education and curriculum / edited by. International perspectives on curriculum studies, Ablex Publishing, London.

10. Boland, T. (1995), Primary Prospects. Development in Primary Education in Some European Countries. A Quest to Facts, Trends and prospects, National Institute for Curriculum Development (SLO), Enschede.

11. Thijs, A. (2009), Curriculum in Development, Netherlands Institute for Curriculum Development (SLO), Enschede, the Netherlands.

12. Jackson, P. W. (1990), Life in Classroom, Teachers College Press, New York.

13. Dewey, John (1998), Experience and Education: The 60th Anniversary Edition. Kappa Delta Pi: West Lafayette IN. 
14. Plachotnyk, O. (2007), "Curriculum as a discourse" in Klepko S. (Ed.), "Challenge for Ukraine: designing framework for general secondary education (national curriculum) for the 21th century", Conference Proceedings, June 26-27, 2007, Kyiv, pp. 117-122.

15. The Newsom Report (1963), Half Our Future, Central Advisory Council for Education, Her Majesty's Stationery Office, London, available at: http://www.educationengland.org.uk/documents/newsom/.

16. Blyth, W. A. L. (1968), English Primary Education: A Sociological Description, Taylor \& Francis, London.

17. Blenkin, G. M. and Kelly, A. V. (1998), "Early childhood education: a developmental curriculum" in Moyles, J. and Hargreaves, L. (Ed.), The Primary Curriculum: Learning from international perspectives, Routledge Falmer, London, pp. 28-42.

18. Meyer, J. W., Kamens, D., Benavot, A., Cha, Y-K. and Wong, S-Y (1992), School knowledge for the masses. World models and national primary curricular categories in the twenties century, Vol. 19, The Falmer, Washington and London, p. 86.

Борисенко I. B., кандидат педагогічних наук, завідувач кафедри іноземних мов, Академія Державної пенітенціарної служби, м. Чернігів, Україна;

Ігнатович T. 3. старший викладач кафедри іноземних мов, Академія Державної пенітенціарної служби, м. Чернігів, Україна КОНЦЕПЦІї КУРИКУЛУМУ В ЗАРУБІЖНІЙ ПЕДАГОГШЦ

У статті досліджено курикулуму в освітніх системах Європейських крайн та визначено підходи до класифікації його типів, рівнів та напрямів розвитку. 3'ясовано, що концептуальні засади змісту освіти Сполученого Королівства визначає теорія курикулуму.

На основі вивчення британської науково-педагогічної літератури виокремлено типи курикулуму: предметно-орієнтований, суспільно орієнтований, дитино-цееттрований; курикулум як зміст, курикулум як процес, курикулум як продукт. Акцентовано увагу на класифікацію його рівнів, а саме: повний, прихований, запланований $і$ отриманий, офіиійний $і$ неофіційний виміри. Наведені визначення акцентують важливість прихованого курикулуму як засобу, за допомогою якого школи привносять соиіальний контекст в офіиійно затверджений курикулум у проиесі його трансляції учням.

Проведений аналіз дозволяє конкретизувати науковий зміст терміна «курикулум» з метою забезпечення ефективності навчального процесу.

Ключові слова: курикулум, кониепт, теорї курикулуму, типи, рівні, Свропейські освітні системи. 